\title{
A LEGÚJABB HYPEREIDÉS-TESTIMONIUM*
}

\begin{abstract}
A Kilian Fleischertől közölt (ZPE 207 [2018] 21-38) új Hypereidés-testimonium (Antipatros követei ellen) elemzése alapján a tanulmány történeti-filológiai érvekkel életrajzi és történelmi adatokat pontosít. Ps. Plutarchos (Vitae X Or. 850A) tudósítását egyértelműen úgy kell értelmezni, hogy Hypereidés Antipatros követeivel szemben Rhodoson Kr. e. 341-ben beszélt az Athénnal kötendő szövetség mellett. Az új töredék másfelől olyan beszédhez köthető, amely Athénban hangzott el a Kr. e. 330-as évek végén, mivel az jól illeszkedik Hypereidés más hasonló, makedónbarát politikusokat támadó beszédeinek sorába.

Kulcsszavak: Fleischer, PHerc. 1021, Col. XI és XII, Ps. Plutarchos, Hypereidés, Rhodosi beszéd, datálás
\end{abstract}

Nemrégiben sokat ígérő tanulmány jelent meg a Zeitschrift für Papyrologie und Epigraphik hasábjain, amelynek címében a szerző új Hypereidés-beszéd felfedezését, két papirusz-oszlopnyi (tehát akár ötvensornyi) szöveg visszanyerését sejteti. ${ }^{1}$ A megfogalmazás bizonyos értelemben helytálló, tudniillik eddig talán ismeretlen beszéd címe (vagy arra való utalás) bukkant fel, a herculaneumi papirusz töredékének tényleges hossza azonban csalódást kelt: a címmel együtt a parafrázis összesen tizenkét sor. A tanulmány azonban így is értékes és fontos adalékkal szolgál a Hypereidés-corpus gyarapításához, még ha túlzásnak is tartjuk az Archimédés-palimpsestusban előkerült terjedelmes töredékek címének („az új Hypereidés”) keresett áthallását e legújabb leletre.

Fleischer a tanulmányában az általa bravúrosan hypereidési idézetként azonosított és több elemében helyreállított szöveg közlése mellett elsősorban a beszéd címének kérdését és - a vonatkozó testimonium elemzése alapján - elhangzásának történelmi körülményeit vizsgálja. E két egységet a hypereidési szöveghagyománynak, illetve az íráshordozó és a szöveg környezetének, az idézet beágyazottságának bemutatása egészíti ki. Az alábbiakban elsőként röviden a szöveghagyománnyal kapcsolatos megállapításokat árnyalom, majd a kiadó közlései alapján a herculaneumi papirusz jellegzetességeit összegzem. Ezt követően a szöveg általam is kollacionált átírását közlöm, amely a készülő Hypereidés Teubner-kiadás része lesz, majd Fleischernek a beszéd címével és azzal összefüggésben a keltezés kérdésével kapcsolatos megállapításait mutatom be, illetve vizsgálom, végezetül pedig észrevételeket, kiegészítéseket közlök, annál is inkább, mert az új töredék kiadója egy korábban közölt felvetésemmel is vitába száll.

* A tanulmány az NKFIH NN 124539 számú pályázat (Társadalmi kontextus a szövegkritika tükrében: Bizáncon innen és túl) támogatásával jött létre.

${ }^{1}$ K. Fleischer: Eine neue Hypereidesrede aus Herkulaneum: Gegen die Gesandten des Antipatros (PHerc. 1021, Kol. 11+12) ZPE 207 (2018) 21-38. 


\section{A Hypereidés-szöveghagyományhoz}

A herculaneumi töredék sajnos kevéssé árnyalhatja a Hypereidés-szöveghagyomány talányos történetét, az ugyanis kétszeresen is csupán közvetett testimonium. Egyfelől Philodémosnak Hermippostól átvett idézeteként, másfelől papiruszon maradt ránk. A középkori szöveghagyomány ugyanis minden bizonnyal teljesen független utakat járt be, semmint azt ezzel a lelettel bármilyen összefüggésbe hozhatnánk. Mivel nincsenek érdemi adataink (ráadásul a szöveghagyomány terén egyes szerzők esetében kiszámíthatatlan tényezők is közrejátszhattak a fennmaradásban vagy a megsemmisülésben), erőltetett megállapításnak érzem, hogy Hypereidés beszéde alighanem már Hermippos idejében ritkaságszámba ment, és az azt idéző, vájt fülü biográfus épp annak ismeretével kívánta volna tudását csillogtatni. ${ }^{2}$ A gondolat - a császárkortól már alig hagyományozott és ismert Hypereidés-szövegek képzete - a kezdő lábjegyzetben köszönettel említett Wilson korábban sokáig fenntartott, majd vonakodva visszavont, szélsőségesen szkeptikus álláspontját tükrözi, miszerint a Hypereidés-szöveghagyomány a késő ókorban megszakadt. A tanulmány kezdő oldalán megfogalmazott tömör összegzés is ugyanennek a szemléletnek a hatásáról árulkodik. Bár a középkori Hypereidés-szöveghagyomány meglétének kérdését valóban az Archimédés-palimpsestus előkerülése zárta le végérvényesen, rá lehet lelni azokra a közleményekre is, ahol e sorok írója 1997-től - az Archimédés-palimpsestus feltárása előtti időkben - amellett érvelt, hogy a Hypereidés-kézirat hagyományozására, puszta létére vonatkozó magyarországi tudósítások hitelesek lehetnek. A jövő nemzedékek magyar filológusai számára is tanulságos megállapítás lehet, hogy a Hungarica non leguntur nemcsak az anyanyelvünkön leírt eredményeinkre vonatkozik, hanem a magyar és a „keleti” szerzők nevével jelzett tanulmányok fölé is vészjósló árnyékként vetül: mindhiába tétetnek azok - különböző magyar érdekű helyeken - indoeurópai nyelveken közzé. ${ }^{3}$ Kivételt csupán a „nyugati

\footnotetext{
${ }^{2}$ Fleischer: i. m. (1. jegyz.) 37.
}

${ }^{3}$ Tényszerűen: a Fleischertől idézett (21. 3. jegyz.) D. Whitehead: Hypereides. The Forensic Speeches. Oxford 2000. 2. 8. jegyz. jóhiszemű hivatkozásában végletesen félreértelmezte a doktori értekezésemben megállapított végeredményt (The Nachleben of Hypereides. Diss. London 1997), és nem ismerte a vezető magyarországi, idegen nyelvű szakmai folyóiratban kiadott, a kommentárja előtt két évvel megjelent tanulmányt: L. Horváth: The Lost Medieval Manuscript of Hyperides. AAHung 38 (1998) 165 skk. „The most recent investigation is in Horváth, Nachleben 9-12 with Appendix I. Horváth succeeds, to my mind, in acquitting Brassicanus' report of either deliberate misrepresentation or naivety, but ultimately, for an explanation, he follows Hose." (Utóbbi nem felel meg a valóságnak.) Az angol nyelven, tágabb összefüggésben is közzétett újabb eredmények sem „nyertek” sokáig kellő figyelmet a Hypereidés-szöveghagyományt tárgyaló szerzők körében: L. Horváth: The Hyperides Corvina. In: Infima Aetas Pannonica. Studies in Late Medieval Hungarian History. Eds. P. E. Kovács - K. Szovák. Budapest 2009. 29 skk. Lásd végül G. Ucciardello: „Iperide tra età tardoantica e medioevo: i percorsi del testo nella tradizione retorica”. In: La tradición y la transmisión de los oradores y rétores griegos. Tradition and Transmission of Greek Orators and Rhetores. Ed. Herdández Muñoz. Berlin 2012. 303 skk. A magyar nyelvű közlést a magyar olvasók figyelmébe ajánlom: L. Horváth: Hypereidés középkori magyarországi hagyománya. In: Uő: Az új Hypereidés. Budapest 2015. 237 skk. 
vérkeringés szívében" megjelentetett, ezáltal mellőzhetetlen írások jelentenek - lásd a De Gruyter kiadványa - a szövegkiadó hivatkozása alapján is. ${ }^{4}$

\section{A herculaneumi papirusz jellegzetességei}

Fleischer Philodemos Index Academicorum (PHerc. 1691/1021 és PHerc. 164) című művének új kiadását készíti elő, amelyben állítása szerint az eddig ismert szövegnek mintegy ötödét javítja, illetve gyarapítja. E munkálatok során állította helyre a Hypereidés-

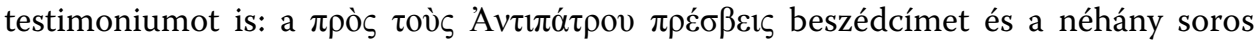

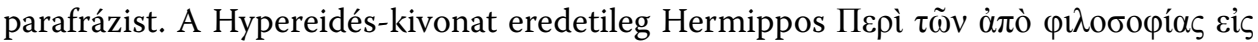

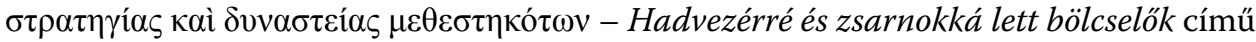
művéből származik, amelyet Philodémos maga is kivonatolt. Fleischer olyan kettőzést fedezett fel a papirusz szövegében, amelynek töredékes szavai között eddig nem figyeltek fel sem Hypereidés (helyreállítható) nevére, sem a beszéd címére, jóllehet azok a szövegszerű ismétlésnek köszönhetően kétszer is előfordulnak.

A zsarnokká lett egykori bölcselők katalógusában Hermippos a pellénéi tyrannos, Chairón rémtetteinek bemutatását vette át Hypereidéstől. Chairón - a Hermippost forrásként használó - Philodémos Index Academicorum címü müvében is kitüntetett helyet kapott, a szerző két teljes columnát szentelt az egykori olimpiai bajnok filozófusnak. Az Index minden bizonnyal Philodémos filozófiatörténeti fogantatású, $\Sigma v ́ v \tau \alpha \xi 1 \varsigma$

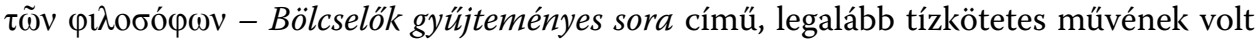
az egyik könyve. ${ }^{5}$ Vélhetően a mü munkapéldányának részletei maradtak ránk a PHerc. 1691/1021 jelzetű papiruszon, míg a végleges változatból csupán elenyésző maradványokat őrzött meg a PHerc. 164 jelzetű papirusz. Ennek megfelelően a PHerc. 1691/1021 szövegében több betoldás, utalás, marginális bejegyzés, törlés és ismétlés, áthelyezésre utaló jel, hátoldali feljegyzés van. ${ }^{6}$ Gaiser ismerte fel, hogy a Chairónra vonatkozó XI. és XII. columna (hasonlóan a Hérakleidés Pontikost tárgyaló IX. és X. columnákhoz) ké-

${ }^{4}$ Fleischer: i. m. (1. jegyz.) 1. 4. jegyz. A jegyzethez tartozó főszövegben: „Dieser »Neue Hypereides« liegt seit 2014 in einer Monographie vor, nachdem die neuentdeckten Reden rege in diversen Beiträgen diskutiert wurden, insbesondere in dieser Zeitschrift." A jegyzetben hivatkozás a 2014-ben megjelent kötetemre a ZPE-ben közölt editio princeps feltüntetésével (a szerzők neveinél javítandó: Carey és Mészáros) és utalással a korábbi irodalmat tartalmazó helyre „siehe Horváth (2014), S. X Fn 8.” Utóbbi a „különféle tanulmányok élénk vitáinak" teljes felsorolása - azok tartalmi elemzése vagy értékelése nélkül.

${ }^{5}$ Fleischer: i. m. (1. jegyz.) 23. 7. jegyz. további szakirodalommal. A nagy mű valamennyi kötetét valószínűleg a Villa dei papiri őrizte.

${ }^{6}$ Fleischer: i. m. (1. jegyz.) 23. és 9. jegyz. vonatkozó irodalommal. 
sőbb, kiegészítésként került be, az időrendi sorrendet ugyanakkor nem törte meg, mert Chairón virágzása valóban Xenokratés és Polemón közé esik. ${ }^{7}$

A két columnára terjedő részlet kivételes sajátossága, hogy mindkét columna záró sorai, különösen a XI.30 skk. és a XII.35 skk. azonos tartalmúak, és a töredékesen fennmaradt részletekből is látszik, hogy szinte szó szerint egyeznek. Több magyarázat is született a különös jelenségre, amelyek közös kiindulópontja, hogy Philodémos Hermippos kivonatolását követően - szándékosan vagy mechanikusan - a feltételezett forrását, Phainiast is kijegyzetelt(ett)e. Fleischer azonban a Philodémos-papirusz átfogó tanulmányozása, a párhuzamba állítható jelenségek alapján eltérő következtetésre jut. A PHerc. 1021-ben két „valódi” ismétlés van (a „valódi” jelző arra utal, hogy egy, már leírt szöveg nagyobb terjedelmü részét a papirusz változtatás nélkül másutt is megismétli). Mindkettő azonos jellegzetességeket mutat. A megismételt szöveg rendre egy-egy columna végén jelenik meg, majd úgy szakad félbe, hogy a következő columna kezdő mondatához egyáltalán nem kapcsolódik. Bár Crönert hasonló hipotézisét cáfolták, elképzelhető, hogy a papiruszban egyes lapokat rendszertelenül, találomra ragasztottak össze. Olybá tűnik, hogy a rövid, ismételt szöveget tartalmazó kivonatot követő új columna mindenképpen új fejezetet kezdett, és a megelőző fejezet végén esetlegesen fennmaradt üres helyre, amolyan sorkitöltésként, korábban már leírt szövegrészleteket írtak. Bár e magyarázatával kapcsolatban Fleischer távolságtartóan óvatos, hozzáteszi, hogy - ha nem is minden esetben - a kettőzések, az ismétlések majdani törlésére vonatkozó jeleket is fel lehet fedezni az íráshordozón. ${ }^{8}$

\section{Az új Hypereidés-testimonium kritikai kiadása}

A szöveg helyreállítása során Fleischer abból indult ki - erre utal a XII. columna alatt látható törlési jel is -, hogy a két columna (XI. és XII.) alján pontosan ugyanaz a görög szöveg állt, így a helyreállításban a sorok kölcsönösen támogatják egymást. Az MSI-felvételek mellett a kiadónak alkalma volt az eredetit és az oxfordi disegnit is tanulmányozni. Mindezek alapján az alábbi kritikai szövegkiadást publikálta. A "` jelek közé tett betűk a disegniben az eredetihez képest jobban olvashatóak, vagy csak abban láthatóak, maradtak fenn. A Fleischertől csillaggal alájelölt (itt félkövérrel szedett és aláhúzott) betủket a disegnihez képest a kiadó javította.

${ }^{7}$ K. Gaiser: Philodems Academica. Stuttgart - Bad Cannstatt 1988. 93 sk. Vö. Fleischer: i. m. (1. jegyz.) 23. 10. jegyz. A Chairónra vonatkozó részletet (PHerc. 1021. col. X.40 - col. XIII.5) Fleischer Verhasselt és Dorandi kiadásai alapján egészében közli, úgy, hogy a korábbi kiadók - az általa felismert, hypereidési szakaszra vonatkozó - eltérő kiegészítési javaslatait kritikai apparátusban tünteti fel: 24 sk. Vö. G. Verhasselt: Hermippus on Chaeron of Pellene (Phld., Acad. Hist., PHerc. 1021, Coll. 10, 40-12, 4 és PHerc. 164, fr. 22 és fr. 24): Edition and Discussion. Cronache Ercolanesi 45 (2015) 33-47, illetve T. Dorandi: Filodemo. Storia dei filosofi. Platone e l'Academia (PHerc. 1021 e 164). Edizione, traduzione e commento. Napoli 1991. A Fleischertől azonosított Hypereidés-parafrázis utolsó sorait a PHerc. 164 is megőrizte (Dorandi fr. 24).

${ }^{8}$ Fleischer: i. m. (1. jegyz.) 26. sk. 
PHerc. 1021. Col. XI,26 - XII,3 (Fleischer)

26

........ ] $\tau^{r} \alpha \varphi \rho \mathrm{\urcorner}^{\urcorner}$vovv-

$\tau \ldots \ldots \ldots] .[\ldots \sigma] \varphi o ́ \delta[\rho] \alpha \pi \varepsilon \rho \mathrm{l}$

$\ldots \ldots \ldots \ldots] \ldots \tau[\hat{v} \rho]^{\top} \alpha{ }^{\urcorner} v-$

$v[\mathrm{o} \tau \tau \tilde{\eta} \varsigma \pi] \alpha \tau \rho 1 \delta \circ \varsigma[\kappa] \alpha \tau \varepsilon \dot{\varepsilon} \sigma-$

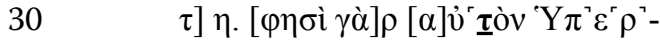

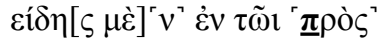

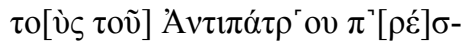

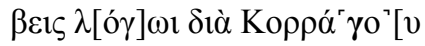

$\kappa \alpha[i] \tau[\tilde{\omega} v] \mu \varepsilon^{r} \tau^{\prime} \dot{\alpha} \tau o v ́ \tau o v$ ' $\not \mathbf{l}$ '-

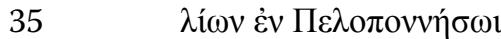

$\sigma \tau \rho \alpha \tau i \omega \tau \tilde{\omega} v \kappa \alpha \tau \alpha \sigma \chi \chi^{\ulcorner} \underline{\mathbf{v}}^{\urcorner}-$

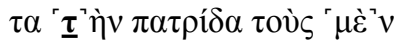

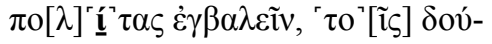

$39 \lambda 01] \varsigma \delta \dot{\varepsilon}[\tau \grave{\alpha}] \kappa \tau \eta \dot{\mu} \mu \alpha \tau \alpha[\tilde{\omega} \nu$

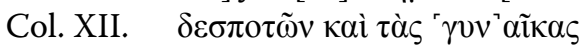

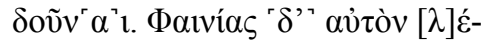

3

' $\boldsymbol{\gamma}$ ' $\varepsilon \iota \kappa \tau \lambda$.

PHerc. 1021. Col. XII,29-39 (Fleischer)

29

30

$\ldots \ldots \ldots \ldots \ldots] . \alpha[] . \pi[$

$\ldots \ldots \ldots] .[\ldots] . \delta \varepsilon$

$\ldots \ldots \ldots \ldots \ldots] \ldots$

$\tau[\dot{v} \rho \alpha v v o \varsigma \tau] \tilde{\eta} \varsigma[\pi \alpha \tau \rho] \operatorname{ó}[\varsigma$

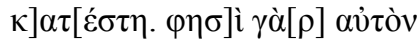

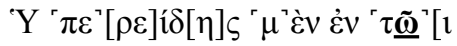

35

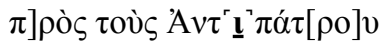

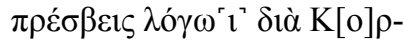

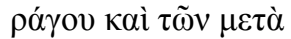

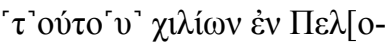

39

$\pi[\mathrm{o}] v v \eta \dot{\sigma \omega \iota} \sigma \tau \rho \alpha\left[\tau \iota \omega \tau \tilde{\omega} v^{9}\right.$

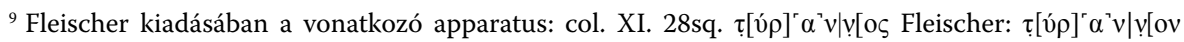

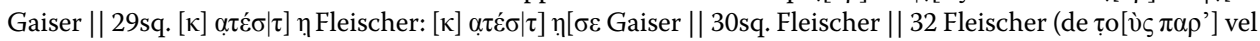

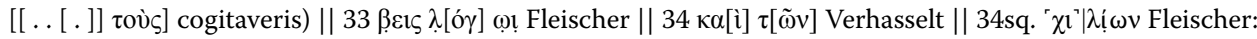
${ }^{\top} \kappa \alpha^{\urcorner} \mid \lambda[\tilde{\omega} \nu$ Gaiser/Dorandi/Verhasselt || $39 \tau[\tilde{\omega} v$ Mekler/Verhasselt || col. XII. $1 \delta \varepsilon \sigma \pi 0 \tau \tilde{\omega} v$ Mekler/Verhasselt

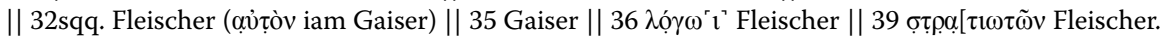


Hazája tyrannosa lett. Hypereidés ugyanis az Antipatros követei ellen című beszédében azt mondja, Korrhagosnak és ezer, a Peloponnésoson állomásozó katonájának segítségével elfoglalta hazáját (ti. Chairón), majd polgártársait száműzte és az urak javait feleségükkel együtt a szolgáiknak adta.

Fabrizio Diozzi, az Officina dei Papiri Ercolanesi - Biblioteca Nazionale di Napoli vezetőjének támogatásával és az MSI-jogtulajdonos Roger Macfarlane (Brigham Young University, Provo, Utah, USA) szíves engedélyével az MSI-felvételekhez magam is hozzájutottam. Az Oxfordban őrzött, a feltárással egy időben, 1795-ben Gennaro Casanovától készített rajz-másolatok (disegni) a világhálón elérhetőek és letölthetőek. ${ }^{10}$ Teljes körű kollacionálást - az autopsia lehetősége nélkül - egyelőre nem végeztem. Mindemellett az MSI-felvételek alapján (a disegnit is figyelembe véve) Fleischer fent közölt szövegrekonstrukciója teljes mértékben megalapozott.

\section{A keltezéssel és a beszéd létrejöttével kapcsolatos megállapítások}

Fleischer szerint Hermippos Hypereidéstől legalább egy mondatot átalakított: azt, amelyben arról van szó, hogy Chairón zsarnokká lett. A címmel kapcsolatban pedig inkább tartja elfogadhatónak az Antipatros követei ellen, semmint az Antipatros követeihez értelmezést. Mivel pedig a beszéd címe másutt nem maradt ránk, értelemszerűen az egyetlen figyelembe vehető testimoniumot elemzi (Vitae X Or. 850A).

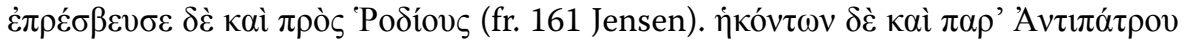

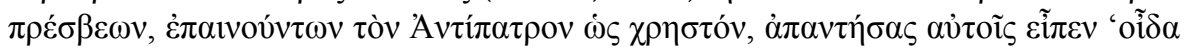

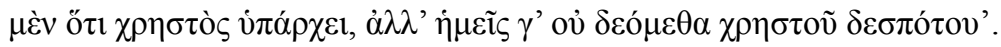

Járt követségben a rhodosiaknál is. Amikor Antipatros szintén odaérkező követei folyvást Antipatros kiválóságáról áradoztak, ezzel vágott vissza nekik: „Tudjuk, hogy milyen kiváló, de ami minket illet, nincs szükségünk kiváló kegyúrra."11

Megállapítja, hogy jóllehet Hypereidés frappáns válasza vándormotívum is lehet (lásd Hippokratés azonos válaszát Xerxésnek: Stob. III.13.51), ${ }^{12}$ tényleges beszédhez is kötődhet. Jensen Hypereidés-kiadásában a 161. töredék alatt az Antiatticista bejegyzé-

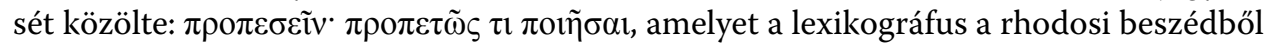

${ }^{10}$ col. XI. http://163.1.169.40/gsdl/collect/PHerc/index/assoc/HASHf503/ede6f142.dir/herc.v0004. n0740.a.01.hires.jpg és col. XII. http://163.1.169.40/gsdl/collect/PHerc/index/assoc/HASH0185/23ede6f1. dir/herc.v0004.n0741.a.01.hires.jpg.

${ }^{11}$ L. Horváth: Az athéni Hypereidés beszédei és stílusának ókori megítélése. Budapest 2001. 16.

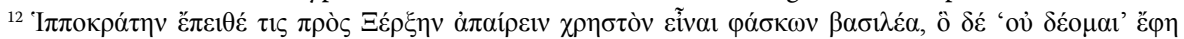

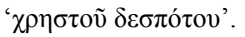




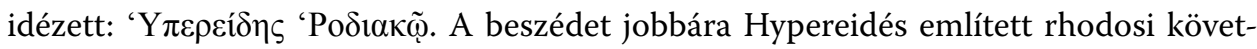
járásához kötik, bár Ps. Plutarchos testimoniumán kívül semmilyen támpontunk nincs. Ma - Fleischer megállapítása szerint - a követjárást a lamiai háborút megelőző időszakra, Kr. e. 323-ra keltezik, szemben a Kr. e. 341. évi, görög szövetségesi hálózat kialakítása

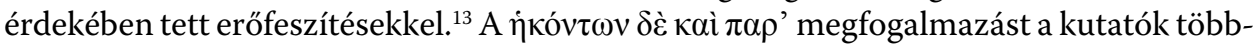
sége összekapcsolja, „egybeolvassa” a megelőző kólonnal, amely Fleischer szerint a Kr. e. 341. évet is kizárná: „was letztlich auch 341 v.Chr. ausschließen würde.”14 Összegezve: az álláspont, amit magam is képviseltem, tudniillik, hogy Hypereidés rhodosi követjárása során az athéni szónok mellett Antipatros követei is megjelentek, Fleischer szerint korántsem megkérdőjelezhetetlen. „Jedoch scheint mir dieses »Zusammenlesen « keineswegs über alle Zweifel erhaben”. Véleménye szerint a megelőző mondatban említett délosi követjárással összhangban egyszerủen újabb követjárást, újabb tételt sorol, ad hozzá a vita, amely inkább a megelőző közléssel van összefüggésben, semmint a folytatással,

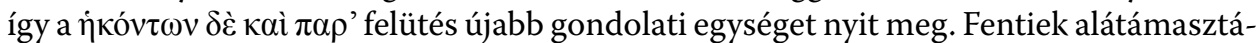

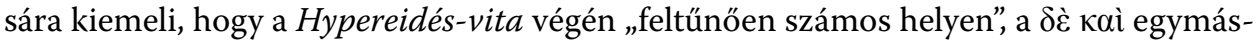
tól elszigetelt adatokat vezet be. ${ }^{15}$ Jóllehet elismeri, hogy a szövegösszefüggés arra utal, hogy Antipatros követei és Hypereidés Rhodoson találkoztak, a kólonokat mégiscsak külön is lehet értelmezni, és ekképpen Antipatros követei Athénban is lehettek, amikor Hypereidés hozzájuk (itt zu, nem gegen) beszélt: „bleibt meines Erachtens möglich, dass die Sätze getrennt zu lesen sind, sprich die Gesandten des Antipatros in Athen waren, als Hypereides zu ihnen sprach". Athénban azonban aligha beszélt a követek jelenlétében, sokkal inkább a népgyülés előtt tett javaslatot, tudniillik: miképpen viszonyuljon az athéni nép a követek képviselte állásponthoz. „Dabei mag er nicht im engeren Sinne gegen die Gesandten in deren Anwesenheit gesprochen haben, sondern lediglich bei der Beratung der Athener Volksversammlung zum Anliegen der Gesandtschaft zu deren Position Stellung bezogen haben." Az általam képviselt felvetéssel kapcsolatban pedig az alábbiakat fogalmazza meg: „Horváth (2014), der die Passage »zusammenliest « und das Jahr 341 v.Chr. annimmt, mutmaßt, ob die Rhodier beide Gesandtschaften nicht gleichzeitig vor der Volksversammlung haben sprechen lassen.” Majd a vonatkozó 51. jegyzetben „szó szerint” idéz: „Horváth (2014) S. 129,130:» Auf Rhodos muss Hypereides auch auf den Vorschlag der makedonischen Gesandten eingegangen sein. Vielleicht liessen

${ }^{13}$ Fleischer: i. m. (1. jegyz.) 32. 48. jegyzetben J. Engels: Studien zur politischen Biographie des Hypereides. München $1993^{2}$. 210. 429. jegyzetére hivatkozik. Engels azonban itt, az Agis-felkelés időszakának diplomáciai tevékenységei kapcsán csupán felveti a vita helyének (Mor. 850 A) Kr. e. 323. évi datálási lehetőségét. Másutt, (vö. alább 34. jegyz.) a monográfiájának főszövegében, majd megismételve az időrendi táblázatban a Kr. e. 341-et valószínűsíti. Ugyanitt (ti. Fleischer: i. m. [1. jegyz.] 32. 48. jegyz.): M. Jehne: Koine Eirene: Untersuchungen zu den Befriedungs- und Stabilisierungsbemühungen in der griechischen Poliswelt des 4 . Jahrhunderts v. Chr. Stuttgart 1994. 235. és H.-U. Wiemer: Krieg, Handel und Piraterie: Untersuchungen zur Geschichte des hellenistischen Rhodos. Berlin 2003. 67. kül. 8. és 9. jegyz.

${ }^{14}$ Fleischer: i. m. (1. jegyz.) 33. és 49. jegyz.

${ }^{15}$ Vö. Fleischer: i. m. (1. jegyz.) 33. és 50. jegyz. Hat helyet idéz, amelyből kettő a rhodosi szövegkörnyezetből van. 
die Einwohner, dem allgemeinen örtlichen Brauch entsprechend, die Gesandten, die mit einem Bündnisvorschlag gekommen waren, gleichzeitig vor der Volksversammlung auftreten, s. Vita X. or. 850 A.« Auch wenn ein Zusammenlesen der Sätze möglich ist, erscheint mir doch fragwürdig, dass Horváth im griechischen Text überhaupt keine In-

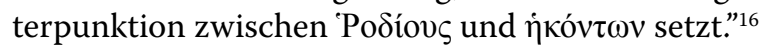

Fleischer az Antipatros követei ellen címmel azonosított beszéd keltezésével és elhangzásának körülményeivel kapcsolatban tehát az alábbi tézisekből indul ki. Ps. Plutarchos testimoniumában a Hypereidés rhodosi követjárását leíró kólont és az azt követő egységet, amelyben az Antipatros követeinek adott válasz szerepel, (inkább) szét kell választani. Ebből az következhet, hogy az Antipatros követei ellen elmondott beszéd Athénban is elhangozhatott. A Rhodiakos és az Antipatros követei ellen címü beszéd tehát nem feltétlenül azonos. Ha pedig mégsem választjuk szét a kólonokat, és a beszéd Rhodoson hangzott el, akkor Kr. e. 323-ban, a lamiai háborút megelőző időszakban keletkezhetett, mert Ps. Plutarchos testimoniumának és a PHerc. részletének, Hypereidés idézett szavainak szellemisége azonos. ${ }^{17}$

A datálás külső támpontjai a következők: 1. Chairón pellénéi uralmának említése Ps. Démosthenés, Az Alexandrosszal kötött szerződésről című beszéd tizedik fejezetében. A beszédet a Kr. e. 336 és 331 közötti időszakra datálják, de a legvalószínűbb Will javaslata, aki azt Kr. e. 333-ra keltezi. ${ }^{18} 2$. Korrhagos veresége és vélhető halála, Chairón bukása az Agis-féle felkelésben, Kr. e. 331-ben. ${ }^{19}$ A Ps. Démosthenés (XVII.) beszéd

${ }^{16}$ Az idézett helyen az itt szereplő „liessen” helyett ließen, „Brauch” helyett Gebrauch, „Vita X. or. 850 A" helyett Vita X Or. 850 A áll.

${ }^{17}$ Másfelől a Kr. e. 341. évi dátum kizárt: az én értelmezésemben azért, mert az Antipatros követei ellen részlete a 330-as évek második felében hatalomra jutott Chairón tetteiről beszél. Fleischer: i. m. (1. jegyz.) 34. 58. jegyz. különös módon nem ezt a kézenfekvő okot említi, hanem azt, hogy Kr. e. 341-ben Antipatros helyett Philippos említését várnánk a makedón követek küldőjeként. „Dass die Rede aus PHerc. 1021 im Jahre 341 v.Chr. auf Rhodos gehalten wurde, ist ob des Bezugs zu Antipatros (eher wäre dann Philipp zu erwarten) unwahrscheinlich”. Az „ex cathedra” kijelentés eredője a Fleischertől másutt hivatkozott Wiemer: i. m. (13. jegyz.), aki művében a 67. oldalon épp így érvel.

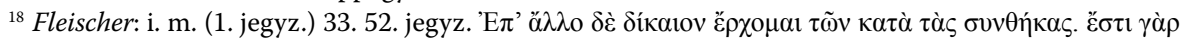

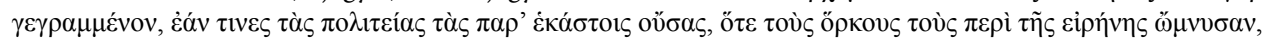

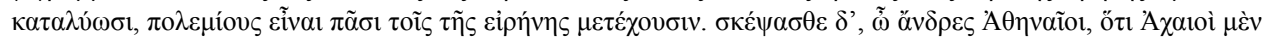

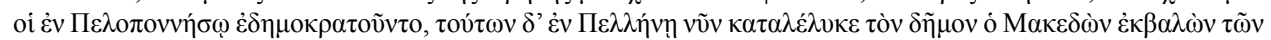

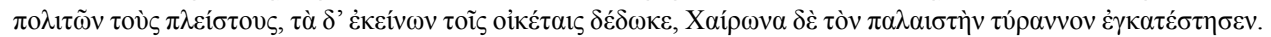
- Most a szerződés egy másik jogos elemére térek rá. Abban ugyanis szó szerint ez áll: aki a szerződés megkötésekor másutt érvényben lévő államformát felszámol, azt a békeszerződés valamennyi tagja ellenségének tekinti. Tessék, athéni férfiak, tekintsétek a peloponnésosi achájok esetét, akik demokráciában éltek, de a makedónok Pellénében megdöntötték a nép uralmát, a polgárok többségét száműzték és javaikat a szolgáiknak adták, Chairónt, a birkózót pedig odaültették zsarnoknak. Lásd L. Horváth: Az Alexandrosszal kötött szerződés (Corpus Demosthenicum XVII.): a szerzőség kérdéséhez. AntTan 57 (2013) 81-91 (javított fordítás).

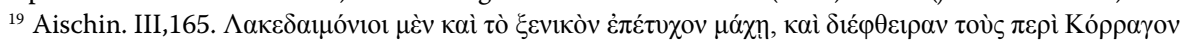

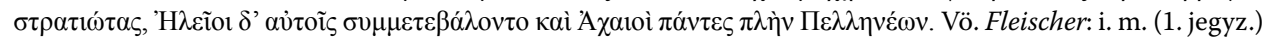
34. 58. jegyz. 
megfogalmazásai (Kr. e. 334-331 között) és a PHerc. szövege (Korrhagos ezer katonájának említése) egyaránt a közelmúltból származó élményeket, eseményeket sejtetnek.

Fentiek alapján Fleischer elképzelhetőnek tartja, hogy az Antipatros követei ellen című beszéd Kr. e. 331 elején hangozhatott el Athénban, amikor Antipatros követeket küldött a városba, hogy biztosítsa az athéniak semlegességét az Agis-felkelésben. Bár ilyen követségről nincsenek adataink, Will és Jehne valószínűnek tartják, hogy az mégis megtörtént. ${ }^{20} \mathrm{Ha}$ Ps. Plutarchos testimoniumának kólonjait elkülönítjük, akkor Hypereidés szavai a (feltehetően) Kr. e. 331-ben Athénban járt követekkel folytatott „párbeszéd” részei lehetnek. Ezt támaszthatja alá a megfogalmazás: $\lceil\mu \varepsilon i ̄ \varsigma \gamma$ ov̉ $\delta \varepsilon o ́ \mu \varepsilon \theta \alpha$, amely inkább az athéni polgárok megszólítására alkalmas. Hypereidés talán csak képletesen szólt a követekhez, mert valószínűleg nem egymás után beszéltek a népgyủlésen, hanem a szónok a követek távollétében adott tanácsot polgártársainak. Arra hívhatta fel honfitársai figyelmét, hogy ha Antipatrosszal szövetkeznek, könnyen arra a sorsra juthatnak, mint a makedónok kegyeltjének, Chairónnak a tevékenysége nyomán Pelléné. Fleischer a gondolatmenetét mindazonáltal mértéktartó óvatossággal zárja, tudniillik a Kr. e. 323. évi rhodosi keltezés sem zárható ki, sőt, Hypereidés akár kétszer is beszélhetett Antipatros követei ellen, kevés a biztos adat, túl sok a bizonytalanság.

Fleischer megállapításaival szemben, tudniillik a Chairónra vonatkozó ókori testimoniumok eredője voltaképpen (csaknem egyértelműen bizonyíthatóan) Hypereidés Antipatros követei ellen címü beszéde, fenntartásaink lehetnek. ${ }^{21}$ Fleischer szerint Hermippos és Démocharés (A filozófusok ellen) Athénaiosnál (11,509a-b) közös forrásból merítettek Chairón tetteinek említésekor, és ez a forrás Hypereidés beszéde volt. A PHerc. 1021, az Antipatros követei ellen Hermippostól parafrazeált megfogalmazásai azonban véleményem szerint nem egyeznek olyan mértékben a hivatkozott források szövegeivel, hogy kategorikus kijelentést tehessünk. ${ }^{22}$ A Ps. Démosthenés-beszéd

${ }^{20}$ Fleischer: i. m. (1. jegyz.) 34. 53. jegyz. A továbbiakban (34) a szerző saját gondolatmenetének öszszegzéseképpen - a kört bezárva - felveti: ha tehát a Ps. Plutarchos-i testimonium kólonjait elkülönítve értelmezzük, akkor e feltételezett, de adatokkal alá nem támasztott athéni követjárásra (további) bizonyítékot nyerhetünk. „Liest man die Stelle in Ps.-Plutarch getrennt, hätte man sogar einen möglichen (weiteren) Beleg für diese Gesandtschaft."

${ }^{21}$ Vö. Fleischer: i. m. (1. jegyz.) 22. ahol Ps. Plutarchos testimoniuma mellett idézi Pausanias és

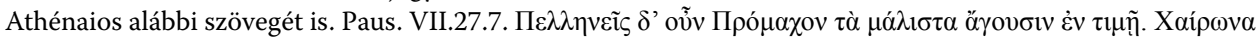

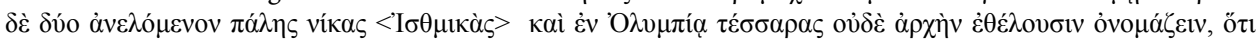

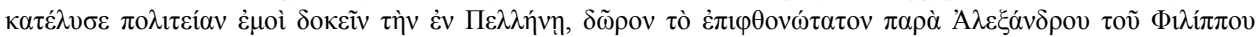

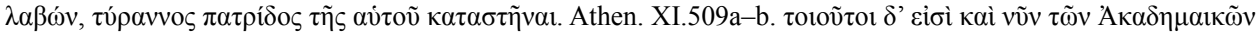

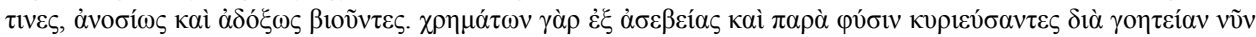

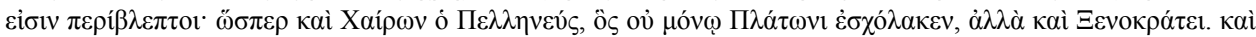

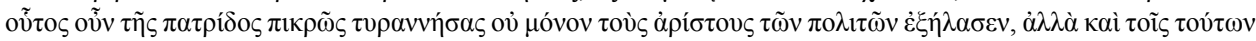

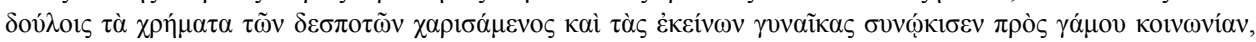

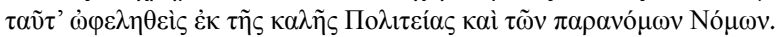

${ }^{22}$ Fleischer: i. m. (1. jegyz.) 35. oly mértékben biztos a forrás megjelölésében, hogy megkockáztatja: „Man könnte weiter fragen, ob in der Hypereidesrede womöglich auch schon ein Bezug zu Platon und Xenokrates vorlag. Dies ist aber wohl eher unwahrscheinlich." 
(XVII) és az Antipatros követei ellen című beszéd részleteinek áthallásával kapcsolatban körültekintőbben fogalmaz: a hatás iránya bármilyen lehet. ${ }^{23}$ Találóan jegyzi meg, hogy a Chairón-történetet a makedónellenes tábor körében gyakran említhették. „Es hat jedenfalls den Anschein, dass die Chairon-Episode im anti-makedonischen Lager gerne angegriffen und verschiedentlich angebracht wurde." ${ }^{24}$ Tegyük hozzá: más hasonló esetek mellett (lásd alább, e tanulmány végén). A Hypereidés beszédére kimondatlanul is utaló sejtetés, tudniillik, hogy Pausanias megfogalmazása (VII.27.7) is valamilyen beszédre vezethető vissza, végképp bizonyíthatatlan. Fleischernek Hermippos Hypereidés-ismereteivel kapcsolatban valószínüleg teljesen igaza van, ${ }^{25}$ mindez azonban nem zárja ki mára elveszett történeti vagy biográfusi források hajdani meglétét. ${ }^{26}$ Ugyanakkor tény és való, miként Fleischer kiemeli, Korrhagos ezer katonájáról kizárólag a most, általa azonosított Hypereidés-beszédből tudunk, az adatot semmilyen más forrás nem tartalmazza, másfelől, lám, Fleischer feltételezése szerint a Hypereidést forrásként használó Démocharés/Athénaios és Pausanias sem. Miként a Hypereidés-szöveghagyomány kapcsán fentebb említettem, az elképzelés, hogy Hermippos egy feledésre ítélt (értsd: alig hagyományozott) szónok, Hypereidés idézésével a mester követőjeként, amolyan kallimachosi, vájt fülű ismereteit kívánta fitogtatni, a mélyen gyökerező wilsoni szkepticizmusra vezethető vissza, tudniillik Hypereidést már a késő ókorban utolérte az általános damnatio memoriae. ${ }^{27}$

${ }^{23}$ A beszéd eredetiségének kérdéséről lásd L. Horváth: Bemerkungen zur Rede XVII im Corpus Demosthenicum: Hypereides als Verfasser (?) In: Demosthenica libris manu scriptis tradita: Studien zur Textüberlieferung des Corpus Demosthenicum. Internationales Symposium in Wien, 22.-24. September 2011. (Wiener Studien Beiheft 36.) Hrsgg. H. Bannert - J. Grusková. Wien 2014. 73-80. A tanulmányt Fleischer nem említi (35. 59. jegyz.). Hypereidés szerzőségével kapcsolatban Bosworth „elszigetelt” álláspontjára hivatkozik (ti. Hypereidés a szerző), majd keresett megfogalmazással hozzáteszi, hogy a Chairón-motívum felbukkanása az Antipatros követei ellen címủ beszédben aligha támaszthatja alá a Ps. Démosthenés-beszéd hypereidési eredetét - a megfogalmazás azonban leplezetten azt sejteti, hogy mégiscsak ezzel a gondolattal kacérkodik: „Jedoch wäre Ps.-Demosthenes 17 selbst in diesem Fall nicht identisch mit der Rede aus PHerc. 1021, da die Stelle im Papyrus nicht mit der Rede überlappt. Ob das durch PHerc. 1021 nun auch für Hypereides bestätigte »Chairon-Motiv« ein (starkes) Argument für Hypereides als Verfasser von Ps.-Demosthenes 17 sein kann, wage ich zu bezweifeln."

${ }^{24}$ Fleischer: i. m. (1. jegyz.) 35.

${ }^{25}$ Fleischer: i. m. (1. jegyz.) 36. A Phryné-beszéd ismeretével és a vonatkozó idézetekkel kapcsolatban lásd Horváth L.: Hypereidés beszéde Phryné védelmében. A töredékek új kritikai kiadása és értelmezése. AntTan 62 (2018) 237 skk.

${ }^{26}$ Lásd a Fleischertől többször idézett J. Bollansée: Philodemos on Chairon, Tyrant of Pellene (PHerc. 1021, Col. 10, 40-12, 41) Historia 51 (2002) 32-48, aki (kül. 13) egy fő történeti forrást vélelmez, igaz, Hypereidés nevének Fleischertől elvégzett rekonstrukciója előtt.

${ }^{27}$ Fleischer: i. m. (1. jegyz.) 37. „Jedoch darf man vielleicht überlegen, ob die Rede zu Zeiten des Hermippos schon eine Art Rarität war und der Autor durch das Wissen um die Chairon-Referenz in dieser Rede, welche ja keine »selbstverständliche« Vorlage für sein Werk war, seine Gelehrsamkeit besonders unter Beweis stellen konnte." 


\section{Észrevételek, kiegészítések}

Az alábbiakban elsőként Ps. Plutarchos (Vitae X Or. 850 A) testimoniumával kapcsolatos korábbi álláspontomat igazolom, majd az új, Chairónt említő Hypereidés-beszéd, az Antipatros követei ellen jellegzetességeihez füzök néhány észrevételt.

Az Antipatros követei ellen című beszéddel kapcsolatba hozható egyetlen testimoniumban, Ps. Plutarchos Hypereidés-életrajzának közlésében (Vitae X Or. 850 A) a rhodosi követségre vonatkozó kólont és az azt követő szakaszt egyértelműen egy egységnek kell értelmezni, „egybe kell olvasni”. A vita szövege ugyan valóban távol áll a műprózától és a közlések, az adatok gyakran szervetlenül kapcsolódnak egymáshoz, ebben a rész-

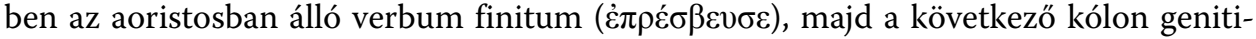

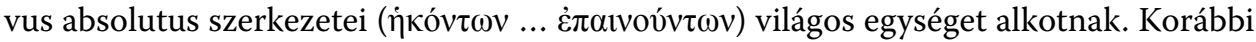
magyar fordításomat markánsabbá is lehet formálni, mert a participiális szerkezetek a fennálló állapotot okhatározói értelemmel fejezik ki.

Hypereidés a rhodosiakhoz is elment követségbe, és mivel Antipatros követei is ott voltak és folyton Antipatros kiválóságát dicsőítették, fellépett velük szemben (vagy akár: a szavukba vágott) és azt mondta: tudom, hogy kiváló, de ami minket illet, nincs szükségünk kiváló kényúrra.

Fleischer okkal teszi fel a kérdést, vajon az „összeolvasásban” valóban el lehet-e merészkedni odáig - miként az a német nyelvű kötetben szemlátomást megjelenik -, hogy a kólonok között egyáltalán nem használunk írásjelet (nincs központozás). Jóllehet a genitivus absolutus szerkezetek előtt használt írásjelek esetében is a kiadók anyanyelvi háttere a meghatározó (egységes szabályrendszer nincs, a német gyakorlat például többször alkalmaz vesszőt, mint az angolszász), itt nem tudatosan mellőztem az írásjelet. Nyomdahiba történt. A 2015-ben, magyar nyelven kiadott, bővített változatban (az érintett oldalakon a német változathoz képest nem változtattam), az első kólon után felpont áll.

Rhodoson Hypereidésnek a makedón követek ajánlatát is ellensúlyoznia kellett. Elképzelhető, hogy az általános szokás szerint a helyiek egyszerre bocsátották a népgyülés elé a szövetségi ajánlattal érkezett küldötteket (Vitae X Or. $850 \mathrm{~A}$ ):

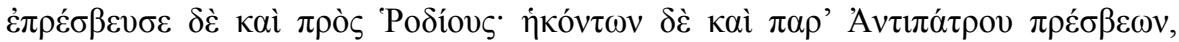

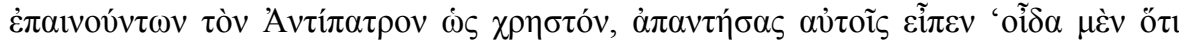

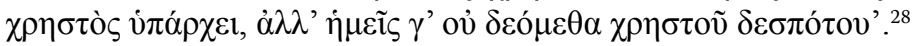

Miként a Fleischertől kritizált német megfogalmazás magyar megfelelőjében is olvasható, valóban olyan helyzet lehetőségét „sejtettem”, ahol és amikor a követek a két nagyhatalom (Athén és Makedónia) rhodosiaknak kínált szövetségi ajánlatát egymást

${ }^{28}$ Horváth L.: Az új Hypereidés. Budapest 2015. 160 sk. 
felváltva adják elő. A rhodosi népgyủlés előtt egyszerre, azaz egymás jelenlétében fellépő követek képzete bizonyíthatatlan, de minden további nélkül elképzelhető. Annál is inkább, mert van rá klasszikus példa, amelyet Démosthenés Koszorú-beszédében (211-214) olvashatunk. ${ }^{29}$ A képlet ugyanaz: a nagyhatalmak (Athén és Makedónia, illetve szövetségeseik) követei a harmadik állam, Thébai szövetségét igyekeznek elnyerni. Gyomlay Gyula fordításában: ${ }^{30}$

Azonban őseitek tetteinek emlékezete egészen magával ragadott, s így egynéhány határozatot $\mathrm{s}$ a követség eredményét még nem is említettem. Visszatérek hát oda, ahol abbahagytam. Mikorára odaérkeztünk Thébaiba, ott találtuk már Philipposnak, a thesszáliaiaknak $\mathrm{s}$ a többi szövetségesnek követeit is, kiknek megérkezésére a mi barátaink persze megfélemledtek, Philipposéi ellenben vérszemet kaptak. $\mathrm{S}$ hogy ezt nemcsak most, a magam haszna szempontjából mondom így, olvasd fel csak annak bizonyságára azt a levelet, melyet mi, követek akkor tüstént útnak indítottunk! Lám, és Aischinés mégis annyira megy a rágalmazásban, hogy ha valami jó történt, az, úgymond, a körülményeknek, nem nekem köszönhető, ellenben, ha más vége lett valaminek, azért mindért engem $s$ az én „balvégzetemet” teszi felelőssé. Eszerint hát nekem, tanácsadó és szónok létemre, abban, aminek sikerüléséhez beszéd meg tanácsadás kellett, nincsen semmi részem, a fegyveres föllépés meg a hadvezetés sikertelenségében azonban egyedül én vagyok a hibás. Hát képzelhető-e ennél arcátlanabb, utálatosabb rágalmazó? Olvasd a levelet. LEVÉL. A thébaiak erre népgyủlést hívtak össze, melyen szövetségeseik címén, az ellenfél követeit fogadták először. Ezek föl is léptek, és beszéltek, dicsérve erősen Philip-

${ }^{29}$ Lásd a 2014. évi német kötetben (L. Horváth: Der „Neue Hypereides”. Berlin 2014.) 93. 11. jegyz., a 2015. évi magyar kötetben 120. 9. jegyz.

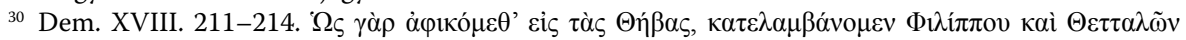

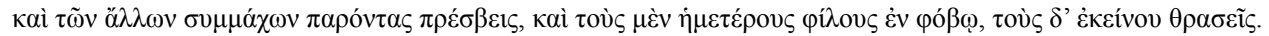

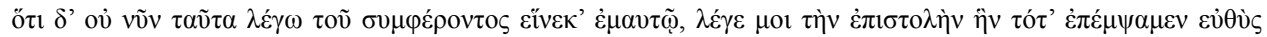

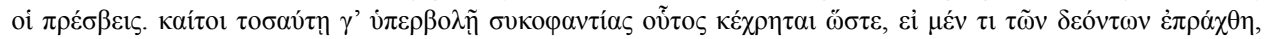

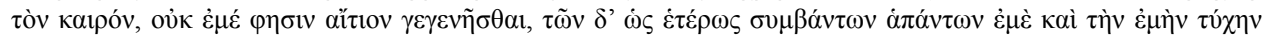

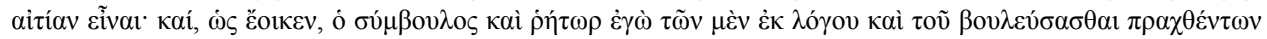

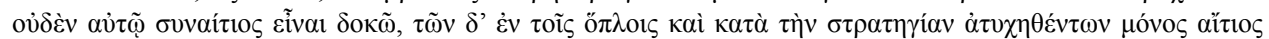

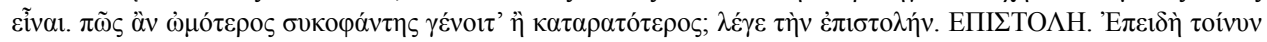

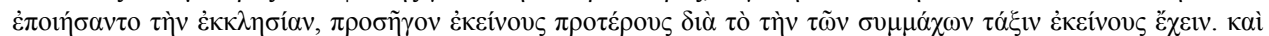

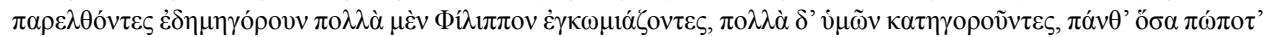

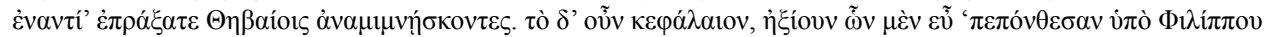

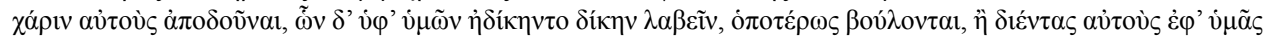

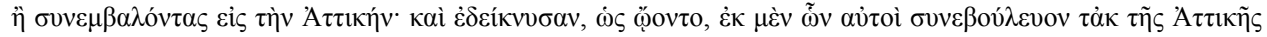

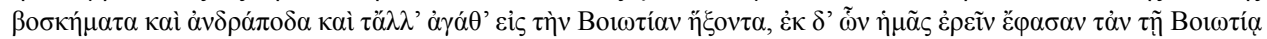

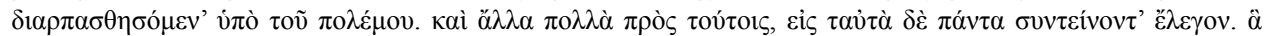

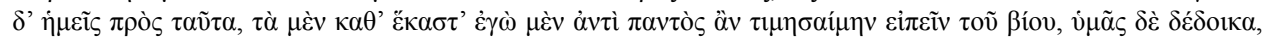

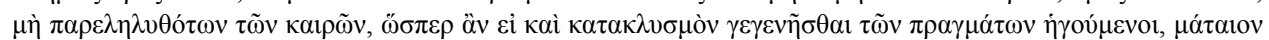

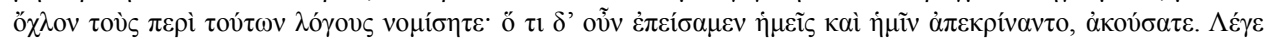
$\tau \alpha v \tau \grave{~} \lambda \alpha \beta \omega ́ v$. 
post, s vádolva keményen benneteket: felhordtak mindent, amit csak valaha a thébaiak ellenére cselekedtetek. Beszédük veleje ez volt: felhívták őket, hálálják meg Philipposnak, ami jót velük tett, rajtatok meg álljanak bosszút azért, amit ellenük vétettetek, már azután akár úgy, hogy szabad átvonulást engednek országukon nekik, akár úgy, hogy hozzájuk csatlakozva ők is rátámadnak Attikára. Meg is értették velük, már tudniillik ahogyan ők gondolták, hogy ha rájuk hallgatnak, hogy fog majd akkor a sok lábasjószág, rabszolga meg más mindenféle drága jó dolog Attikából Boiótiába átkerülni; ellenben, ha a mi tanácsunkra hallgatnak, csak azt érik el vele, hogy akkor maga Boiótia lesz a háború martaléka. Sok mást is mondtak még, de mind csak erre célzott. Hogy mármost mit feleltünk mi erre, azt én persze sokért nem adnám, ha részletesen előadhatnám; de hiába, elmúltak azok az idők, s ti tán úgy gondolkoztok, hogy az idők árja magával sodorta azokat az eseményeket is. Attól tartok hát, hogy hiú szószaporításnak vennétek a hosszabb fejtegetéseket erről a dologról; halljátok tehát csupáncsak azt, ami beszédünk sikerét mutatja; a thébaiak hozzátok intézett válaszát. Vedd elő csak és olvasd fel!

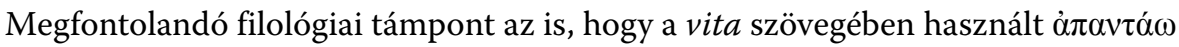
ige a törvényszéken, a vitákban az ellenfél ellen fellépő érvelést is jelenti. Sőt, annak a cselekvésnek a terminus technicusa, amikor a bírák, a hallgatóság felhördülve a beszélö-

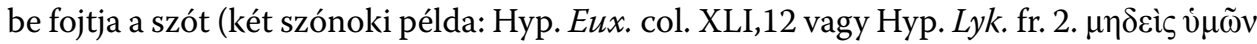

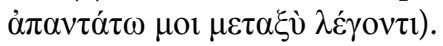

Elképzelhető, hogy Rhodoson is a szövetségi választás mérlegelése folyhatott. Az életrajzban idézett szállóige, Hypereidés kijelentése szépen beleillene egy, a makedónok nagyszerüségét taglaló beszédre adott csattanós válaszba. A i $\mu \varepsilon i ٓ \varsigma \gamma^{\prime}$ ở $\delta \varepsilon o ́ \mu \varepsilon \theta \alpha$ többes szám első személyü, athéniakra (is) értett megfogalmazás sem idegen ettől az elképzelt helyzettől (nem feltétlenül Athénba kell tehát helyeznünk a jelenetet). Mindezt az athéni követ és szónok akképpen mondhatta magukra vonatkoztatva, hogy immár a rhodosiakat is beleértette, és a szigetlakók szabadságszerető érzelmeire célzott.

Összegezve tehát, az általam korábban felvetett és most is fenntartott lehetőség, tudniillik, hogy Hypereidés rhodosi követjárása során Antipatros követeivel szemben/ ellen szólt, talán nem is annyira vakmerő (spekuláció - Mutmaßung), mint Fleischer új felvetése, aki a rhodosi követjárástól elszakítva egyszerűen Athénba helyezi a Ps. Plutarchos szövegében foglalt történéseket.

Miként azt Fleischer kiemeli, a rhodosi eseményeket Kr. e. 341-re kelteztem. Másfelől azt állítja, ha a szöveget valóban egybeolvassuk, akkor ez a datálás kizárt. Mindebből az következik - bár ezt expressis verbis nem mondja -, hogy önmagamnak mondtam ellent. Az alábbiakban tisztázom, hogy ez nincs így, tehát a szöveget egységben kell és lehet értelmezni, és mindez egyáltalán nem zárja ki a Kr. e. 341. évi datálást. Mindennek a Fleischertől felfedezett, Antipatros követei ellen címü beszéd keltezése szempontjából nincs érdemi jelentősége, mert azt semmiképp sem lehet Kr. e. 341-re datálni (akárhol is hangzott el). Az ok, mint fentebb írtam, kézenfekvő: Hypereidés Kr. e. 341-ben nem beszélhetett Chairón pellénéi rémtetteiről, mert azok legkorábban Kr. e. 338 után 
történhettek. Fleischer azonban a Kr. e. 341-es dátumot - az Antipatros követei ellen összefüggésében (!) - nem emiatt zárja ki, hanem azért, mert akkor a vita szövege nem Antipatros, hanem Philippos követeiről beszélne Rhodoson. ${ }^{31}$ Jóllehet Fleischer maga is többször hangsúlyozza, hogy a szónokok szóhasználatában a makedónok és néven nevezett vezetőik szinte „csereszabatosak”, és a népnév és a tulajdonnevek a makedón külpolitika képviselőire általában vonatkoznak, Antipatros követeinek (nem általánosított, „makedón” értelemben értve) és Hypereidés rhodosi összecsapásának Kr. e. 341. évi lehetősége nem emiatt védhető, ha úgy tetszik, elképzelhető.

Támpont lehetne a vitában említett rhodosi követjárás biztos keltezése. Fleischer szerint a régebbi szakirodalom a Kr. e. 341. évet, az újabb azonban a Kr. e. 323. évet valószínűsíti. ${ }^{32}$ Démosthenés és Hypereidés rendkívül aktív diplomáciai, illetve tényleges katonai tevékenységével kapcsolatban magam is - az ókori forrásokat áttekintve és a szakirodalomtól támogatott keltezések prótos heuretéseit is felkutatva (Kiessling, Böhnecke, Schäfer, Boeckh) végeredményben - a Kr. e. '40-es évek végét tartottam (és tartom ma is) valószínűbbnek. ${ }^{33}$ A hellén szövetségi hálózat - Byzantiontól a szigeteken át a Peloponnésosig - létrehozására Kr. e. 341-ben és Kr. e. 323-ban egyaránt jelentős erőfeszítéseket tettek az athéniak, de az adatokkal alátámasztható aktivitás mértéke a mérleg nyelvét - számomra egyértelműen - inkább a Kr. e. 341. évi datálás felé billenti. Hypereidés rhodosi követjárásának keltezésével kapcsolatban valóban végletesen megoszlanak a vélemények. Ezeket Wiemer a jegyzeteiben tételesen felsorolja, miközben maga végül a - Fleischertől is megismételt - főszövegében Kr. e. 323 mellett kötelezi el magát. A Kr. e. 341-et kizáró ok: nem Philippos, hanem Antipatros követeiről beszél a testimonium. ${ }^{34}$

Véleményem szerint azonban igazolható, hogy Antipatros neve Kr. e. 342-341-ben is a makedón követek mellett szerepelhetett. Philippos ugyanis a thrák törzsek ellen vívott hadjáratai idején régensként Antipatrost bízta meg az államügyek irányításával. Az euboiai események kapcsán is kimutatható a kiváló hadvezér és diplomata meghatáro-

${ }^{31}$ Fleischer: i. m. (1. jegyz.) 34. 58. jegyz. Lásd Wiemer hatásáról fent a 17. jegyzetben.

${ }^{32}$ Fleischer: i. m. (1. jegyz.) 32. 48. jegyz. Lásd a 13. jegyz. A főszövegben: „Diese Gesandtschaft nach Rhodos wird heute von der Forschung eher auf werbende Aktivitäten Athens vor dem Lamischen Krieg (323 v.Chr.) und nicht mehr auf Werbung für den Hellenenbund im Jahre 341 v.Chr. bezogen." Vö. 13. és 33. jegyz.

${ }^{33}$ Horváth: i. m. (28. jegyz.) 129 skk.

${ }^{34}$ Wiemer: i. m. (13. jegyz.) 66 sk. és 6-9. jegyzetek. A szerző Kr. e. 323 (7. jegyz.) és Kr. e. 341 (8. jegyz.) „hívei” mellett a non liquet álláspont képviselőit is felsorolja (ugyancsak a 8. jegyz.). Jól érzékelteti a kérdés szövevényes voltát, hogy Engels Wiemernél (Hypereides², 87 mit Anm. 150) Kr. e. 341-et, Fleischer szerint azonban (32. 48. jegyz.: Engels [1993²], S. 210, Fn. 429) inkább Kr. e. 323-at részesíti előnyben, jóllehet utóbbi helyen nem a rhodosi követjárásra, hanem egy, az Agis-felkelés időszakában, Athénban vélelmezett diplomáciai tevékenység kapcsán említi ismét a szerző (Engels) a vita helyét (vö. 13. jegyz.). Hogy mennyire inkább a Kr. e. 341. évi keltezést részesíti előnyben, bizonyítja a 415. oldalon közölt időrendi tábla. 
zó szerepe. ${ }^{35}$ Kr. e. 342 szeptemberében a pythói játékokon is a királyt helyettesítette. ${ }^{36}$ Antipatros tehát nemcsak Alexandros európai régenseként (Kr. e. 334 után) küldhetett követeket bárhova, hanem Philippos régenseként is Kr. e. 342-341-ben. ${ }^{37}$

Összegezve tehát: a Hypereidés-vitában olvasható testimonium (850 A) minden bizonnyal Hypereidés Kr. e. 341. évi követjárását említi, amikor a sziget szövetségét a makedónok, az Antipatrostól küldött követek is biztosítani akarták maguknak. Hyper-

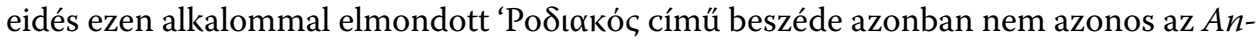
tipatros követei ellen című beszéddel, amelynek Hermippostól idézett, Chairónnal kapcsolatos részletét Fleischer azonosította. ${ }^{38}$

Bár - miként a szerző maga is megvallja - egyértelmű támpontok, adatok nincsenek, valószínü, hogy a most azonosított beszéd valóban Athénban hangzott el a Kr. e. 330-as évek végén, akár Kr. e. 331-ben. Ezt a lehetőséget az alábbiakban - a Fleischertől idézett Ps. Démosthenés XVII.10 mellett - két további beszéddel, illetve szöveghellyel szeretném alátámasztani. Mindkettő ugyanabban a szellemiségben fogant, sőt, hasonló megfogalmazásban született, mint amiről a Chairónra vonatkozó részlet árulkodik. Hypereidés a makedónbarát hazaárulók kérlelhetetlen ostorozója: egyenként és név szerint kárhoztatja őket több beszédében. Az első immár ismert példa a Dióndas ellen című beszéd hazaáruló-katalógusa, amelyben szónoki kérdésekbe ágyazva vezeti be azoknak a névsorát, akik a görög államokban a makedónok pártjára álltak. ${ }^{39} \mathrm{~A}$ beszéd Kr. e. 334 télutóján hangzott el, és a katalógus alighanem müfajt teremtett. Négy évvel később, Kr. e. 330-ban Démosthenés a Koszorú-beszéd 295. fejezetében ugyanabban a szellemben tovább bővítette a névsort. (Chairón neve Démosthenésnél sem szerepel.) A makedónellenes politikusok kedvelt témája volt a hazaárulók megbélyegzése, legyen szó akár közismertebb alakokról, mint például az argosi Mnaseas, vagy „másodhegedű-

${ }^{35}$ Lásd Horváth: i. m. (28. jegyz.) 133. sk. a vonatkozó szakirodalommal. J. B. Scholten: Antipater. In: The Encyclopedia of Ancient History. Eds. R. S. Bagnall - K. Bordersen - C. B. Champion - A. Erskine - S. R. Huebner. Wiley-Blackwell 2013. 484. „[S]erved as regent in Philip’s absence” - a szerző Isokratés 4. levelére és Plut. Alex. 9.1-re hivatkozik.

${ }^{36}$ N. G. L. Hammond - G. T. Griffith: A History of Macedonia. II. 550-336 B.C. Oxford 1979. 725 (az időrendi felsorolásban). Az euboiai események kapcsán Uö: 546. „It seems possible, for example, that requests for troops from Macedonia by leaders in Euboean cities were answered by Antipater without the long delay of communicating with Philip in eastern Thrace." Épp a Kr. e. 341. évi euboiai athéni sikerek miatt erősödött fel Démosthenés és politikustársainak diplomáciai tevékenysége.

${ }^{37}$ Hypereidés rhodosi követjárásának Kr. e. 341. évi keltezését támasztja alá bizonyos mértékben az is, hogy a vita megelőző bejegyzése a Kr. e. 343. évi delphoi sikerét említi a délosi perben (a pontos dátumot illetően eltérnek a vélemények. Vö.: Engels: i. m. [13. jegyz.] 79. és H. Wankel: Demosthenes Rede über den

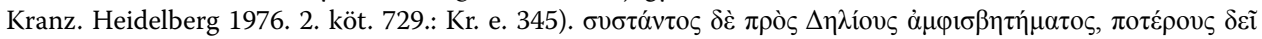

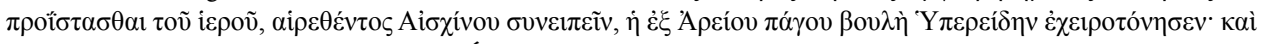

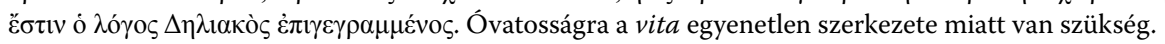

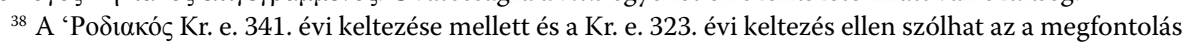
is, hogy - még ha sikeres is volt a szövetséget összekovácsoló beszéd - a lamiai háború forgatagában aligha maradhatott ideje Hypereidésnek arra, hogy publikálja. Valószerűbbnek tűnik, hogy a szónok a Kr. e. 341-338 közötti diplomáciai sikersorozat egyik markáns elemeként tehette közzé a beszédét.

${ }^{39}$ Hyp. Dion. 21. Lásd Horváth: i. m. (28. jegyz.) 78. és 155 sk. 
sökről”, mint Athénogenés. Az Athénogenés ellen című beszédében ugyanis Hypereidés ugyanilyen szellemiségű invektívát intéz a vádlott ellen Kr. e. 330 és 324 között. ${ }^{40} \mathrm{Az}$ általam kollacionált (a XVI. columna első sorában javított és helyreállított) szöveghely alapján Athénogenés troizéni és Chairón pellénéi rémtetteinek leírása között szembetünő a hasonlóság. ${ }^{41}$

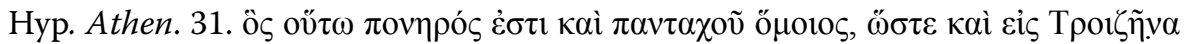

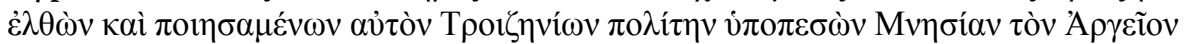

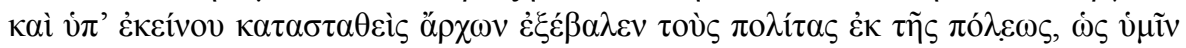

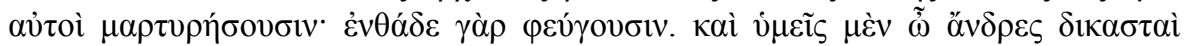

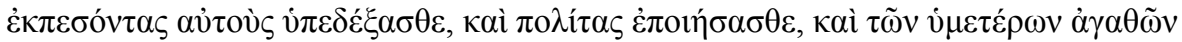

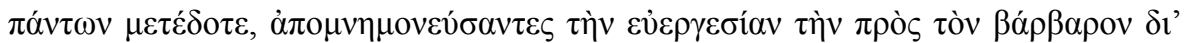

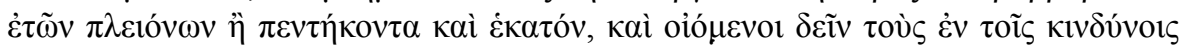

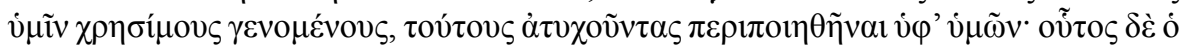

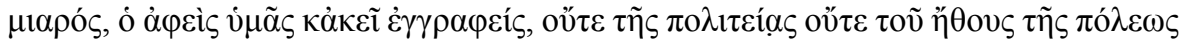

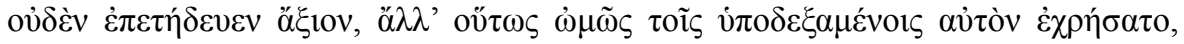

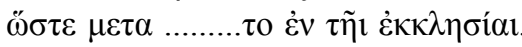

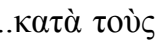
$\varphi \rho o v \rho \grave{\alpha} v \delta \grave{\varepsilon}$

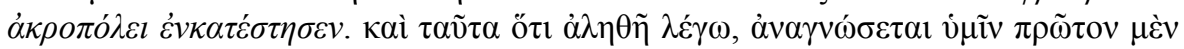

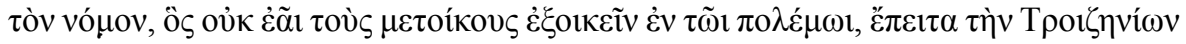
$\mu \alpha \rho \tau v \rho i ́ \alpha v \ldots$

Mert aljas ember ő, éspedig mindenütt és egyformán aljas; Troizénban például bevándorlóként polgárjogot kapott a troizéniaktól, mégis az argosi Mnésias szolgálatába állt, aztán a tőle ráruházott tisztséggel visszaélve kiűzte a polgárokat városukból, s ezt ők maguk fogják nektek tanúsítani, hiszen száműzetésüket nálunk töltik. Igen, tisztelt bírák, ti befogadtátok a kivetetteket, polgárjogot adtatok nekik, és minden javatokat megosztottátok velük, mert nem felejtettétek el a barbárokkal szemben több mint százötven évvel ezelőtt nektek nyújtott segítséget, s mert mindig is úgy gondoltátok, ha veszélybe kerülnek azok, akik a bajban egykor titeket támogattak, nektek kell róluk gondoskodnotok. Ez az átkozott viszont, aki

${ }^{40}$ A datáláshoz lásd Whitehead: i. m. (3. jegyz.) 266 sk.

${ }^{41}$ L. Horváth: The Vicissitudinous History of the Athenogenes-Papyrus and its Edition. AAHung 49 (2009) 507-522. A XVI. columna 1-7. sorainak kritikai kiadását az 522. oldalon függelékben közöltem (ugyanez a Col. XV.24 - XVI.6. sorok kiadásával. In: Pietas non sola Romana: Studia memoriae Stephani Borzsák dedicata. Eds. A. Czeglédy - L. Horváth - E. Krähling - K. Laczkó - D. Á. Ligeti - Gy. Mayer. Budapest 2010. 108). A helyreállítás pontos leírása az Antik Tanulmányokban olvasható: Komikus áthallások a szónoki érvelésben (Hypereidés Athénogenés elleni beszédének felépítése). 50 (2006) 36-56. kül. 42 sk. A szöveget

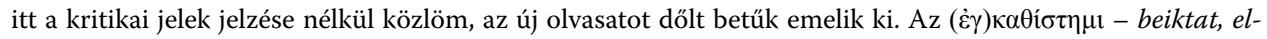
helyez ige különböző alakjai rendre felbukkannak ezeken a többé-kevésbé Hypereidéshez köthető helyeken:

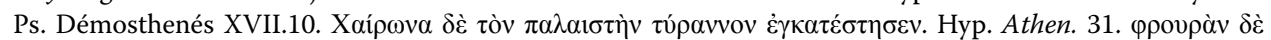

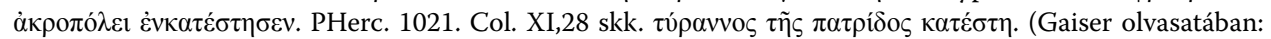
$\kappa \alpha \tau \varepsilon \dot{\sigma \tau \eta \sigma \varepsilon .)}$ 
titeket elhagyott és amott vétette fel magát polgárnak, meg sem próbált a város szelleméhez és a törvényekhez méltón viselkedni, hanem olyan könyörtelenül bánt befogadóival, hogy ... a népgyülésen ... helyörséget helyezett el a fellegvárba. Állításaim igazolására elsőnek azt a törvényt olvastatom fel nektek, amely megtiltja a betelepült idegenek kivándorlását háborús időszakban, azután a troizéniak tanúvallomását...

A Fleischertől azonosított Antipatros követei ellen című beszéd tehát jól illeszkedik Hypereidés szónoklatainak sorába, amelyeket a Kr. e. 330-as évek második felében, illetve a 320-as évek első felében a makedón talpnyalók és helytartók ellen mondott el a törvényszékek vagy a népgyülés előtt.

\section{SUMMARY}

On the basis of the analysis in the new Hyperides testimony (Against the Emissaries of Antipater) published by Kilian Fleischer (ZPE 207 [2018] 21-38), this paper updates biographical and historical data using historical-philological arguments. The report of Ps. Plutarch (Vitae X Or. 850A) must evidently be interpreted to the effect that on Rhodes, in $341 \mathrm{BC}$, Hyperides spoke in favour of a prospective alliance with Athens, countering the emissaries of Antipater. In addition, the new fragment can be connected to a speech delivered in Athens towards the end of the 330s BC as it harmonizes well with other, similar speeches made by Hyperides against pro-Macedonian statesmen.

Keywords: Fleischer, PHerc. 1021, Col. XI and XII; Ps. Plutarch; Hyperides; Speech on Rhodes; Dating

Horváth László

ELTE BTK Görög Tanszék

ELTE Eötvös József Collegium

horvathl@eotvos.elte.hu

A cikk a Creative Commons Attribution 4.0 International License (https://creativecommons.org/ licenses/by/4.0) feltételei szerint publikalt Open Access közlemény, melynek szellemében a cikk bármilyen médiumban szabadon felhasználható, megosztható és újraközölhető, feltéve, hogy az eredeti szerző és a közlés helye, illetve a CC License linkje és az esetlegesen végrehajtott módosítások feltüntetésre kerülnek. (SID_1) 